UDC 332

\title{
THE TRANSFORMATION PATTERN OF ECONOMIC AND LABOR STRUCTURES IN THE DEVELOPMENT OF INDONESIA (2007-2017)
}

\author{
Maryam St. * \\ Faculty of Economics and Business, Universitas Mataram, Indonesia \\ *E-mail: maryamnanang@gmail.com
}

\begin{abstract}
Structural transformation is a prerequisite of the improvement and sustainability of growth and poverty reduction as well as a support for the sustainability of development itself. Another important aspect of structural change is the employment that the economic growth through two processes of transformation can be achieved by increasing the labor productivity in each sector and transferring labor from the low labor productivity sectors to higher labor productivity. This study aims to explain the pattern of the transformation of the economic structure and labor structure Indonesia in 2007-2017. The data used is the Gross Domestic Product ( GDP ) and Employment in the Main Employment. The results show the existence of transformation of the economic structure and labor structure Indonesia. Economic structure transformation includes Primary - Secondary - Tertiary patterns. Meanwhile, the transformation of labor structure patterned on the Primary sector - Tertiary - Secondary. The contribution of the primary and tertiary sectors to the PBD is increased, while the secondary sector has declined. The role of the primary sector in employment is decreased further, while the secondary and tertiary sectors are increasing.
\end{abstract}

\section{KEY WORDS}

Economic sector, jobs, gross domestic product.

The economic development process is typically followed by changes in the changes in the economy's structure including the economic and labor structures. The structural changes happen due to the interaction between accumulation and consumption process under the influence of income per capita. The pattern transformation of market demand toward the consumed goods changes the composition and services produced and traded. Besides, it also changes the labor orientations upon the main choices of employment.

Structural transformation is a prerequisite of the improvement and sustainability of growth and poverty reduction as well as support for the sustainability of development itself. Generally, an economic development is aimed to improve the welfare and prosperity which can be defined as a degree of basic needs fulfillment. According to Tulus T. H. Tambunan, 2001 , economic growth without an increase in employment rate will constitute an inequality in the distribution of income (ceterisparibus). The inequality itself can create an economic growth with an increased poverty rate.

It has been acknowledged by economists that economic and labor structures will have changes in its development process (Sukirno, 1985). The changes of the production structures in a developing economy are typically shown by the declining role of agriculture sector toward the Gross Domestic Product (GDP) and its role in absorbing the number of the labor force can be seen from the percentage of GDP distribution and the number of employed population. The historical experience shows that the economic structure of countries across the globe have experienced transformations in its economic growth and development process. The economy, as well as labor structural changes, are mainly reflected in the role of economic/labor sectors (the main employments which determine the national production along with the percentage of labor in each economic/business fields/main employment sector (Kamaludin, 1998).

The economic structure established in a region is determined by the role of each economic sector in creating value-added to the sector. Meanwhile, the labor structure established is determined by the role of each business field/main employment in absorbing 
the labor force. In other words, the economic and labor structures can be used as a reflection which shows the dependency of a certain region toward the reproduction capability of each economic sector and the ability to absorb labor force for each main employment.

The transformation pattern of economic and labor structures is an important indicator to evaluate the development in a particular area (State/region), even though there are some opinions advising not to be too oriented solely on the growth and also consider the improvement of the human resources. Realistically, an economic development has wider coverage than a mere economic development. Therefore, the orientation of an economic development is no longer about the growth, but should also be about the transformation of the economic and labor structures, equity and justice as well as community economic empowerment

According to the history of economic growth, the now developed countries show an important characteristic which is the high rate of structural and sectoral transformation happened during the growth process. Some essential components of this structural change include a gradual shift from agricultural practices to non-agricultural practices, and more recently, a shift from industrial practices to practices in the sector of services, a quite major change according to the scale or average unit production size, which is the change from family-based company or private into a big organization (not organized by one particular family) which is national and multinational companies, and the last one is the relocation into the suitable area/location and of the employment status from the employment in rural areas' agriculture and non-agriculture which is still related, to become a member of the communityoriented to the industry and services in urban areas (Todaro, 1983)

A.G.B.Fisher in International Labour Review of 1935 stated that a couple of Countries can be differentiated by its percentage of labor in the primary, secondary, and tertiary sector. This argument is proven by Clark (1949, in Suryana 2000) who had collected the statistical data on the percentage of labor worked in the primary, secondary, and tertiary sector in several countries. The data collected show that the higher the income per capita of a Country, the role of agriculture sector in providing employment. Yet, on the contrary, the industrial sector has a stronger role in absorbing labor force. The primary sector in that research refers to the economic practices in the field of agriculture, forestry, fisheries, and mining. The secondary sector is manufacture industries, water and electricity, and construction. The tertiary sector includes practices in the field of shipping and transportation, government, trade, and private services.

The prominent model of structural transformation pattern is the one proposed by Hollis B. Chenery. The important factors, according to Chenery, are the transition flow of the agricultural economic pattern into an industrial economy, the continuity of physical and human capital accumulation, the transformation of consumer demand, the development of urban areas related to the migration of employment seekers, and agricultural areas in rural and suburb areas. Chenery stated that the structural transformation process has positive and negative impacts. One of the negative impacts is the intensified stream of urbanization which aligns with the degree of industrialization. The industrialization and urbanization in several aspects will only be positive if it is accompanied by the equal learning opportunities, the decrease in population growth, and the decrease in the degree of the dualistic economy between urban and rural areas (Pambudi, 2011).

Throughout the process of economic development, the agriculture sector is transformed. Thoroughly observed from all economic sectors, a transformation has happened in a form of the declining contribution of the agriculture sector toward GDP (Gross Domestic Product) and the employment it creates. It can be caused by the increase of the general standard of living and the demand related to goods and service consumption so that the proportion of human resources allocated to the production sector of non-agriculture is heightened. In the developed countries the likes of West Europe and the United States, the labor force in agriculture sector is less than ten percent, while in the developing countries, the employment rate in agriculture sector is around 30 percent (Hakim, 2004). This demography has become the basic perception of how a development should be implemented. The industry is regarded as the leading sector in the development and should 
be advanced, while the agriculture is regarded as a sector which role is naturally declining, and the decline should be sped up and replaced by the industrial sector if necessary. It has reinforced some Countries to adopt such negative policies toward agriculture, and speed up the shift of human resources investment from agriculture to industrial and public sector (Hakim, 2004).

The structural transformation happened in some developed countries including the United States, West Europe, and Japan, started by the fast industrial expansion creating labor forces demand so that there was a transfer of labor force from the agriculture sector to the manufacturing sector. In time, this will increase the living standard in rural areas and lower the population of land, smoothen up the agriculture re-organization into a bigger agroindustrial company. The agricultural efficiency improvement also has a significance in fulfilling the increasing food needs of labor in urban industries. This proves that the modal required to fund the industrial expansion, at least at the beginning of the development, is primarily obtained from the agriculture sector.

Structural transformation is a prerequisite of the improvement and sustainability of growth and poverty reduction as well as a support for the sustainability of the development. In fact, Indonesia's economic growth is not accompanied by a proper transformation of labor structure, which means the turning point for the economic practices is achieved prior to the turning point of the labor force. Therefore, there are problems which are often debated whether the GDP share aligns with the decline of sectoral labor force absorption and which industry is developing faster, agro-industry or manufacture industry. If the transformation is not balanced, it is prone to impoverishment and exploitation toward the human resources in the primary sector. The process of economic structural transformation in Indonesia is marked by 1) a decline of share in the primary sector (agriculture) 2) an increase of share in the secondary sector (industry) 3) the share of service sector more or less constant, yet its contribution will improve in accordance with economic growth (Tambunan, 2001)

According to Clark, another important aspect of structural change is the employment that the economic growth through two processes of transformation can be achieved by increasing the labor productivity in each sector and transferring labor from the low labor productivity sectors to higher labor productivity (Gultom, 2011).

The history of economic growth in developed countries indicates the importance of the high level of structural and sectoral development toward the process of economic development. The main components of the structural transformation include the shift from agricultural practices toward non-agricultural. The economic growth had caused structural changes in the economy. The structural transformation itself is a process of structural change in the economy from the agriculture sector to the industrial sector, trade and service, wherein each economy will have a different transformation. Chenery: "generally the transformation in developing countries is a transformation from the agriculture sector into the industrial sector. The structural change or economic transformation from traditional into modern generally can be defined as a transformation in the economy related to the composition of labor force absorption, production, trade, and other factors required continuously to improve the income and social welfare through the increase of income per capita" (Gultom,2011).

Furthermore, according to Tambunan (2001), in analyzing the economic structure, there are two main theories, which are theory from Arthur Lewis (migration theory) and Hollins Chenery (theory of structural transformation). Lewis assumed that a country's economy is basically divided into two, traditional economy into rural areas dominated by agriculture sector and modern economy in urban areas with industries as its primary sector. In rural areas, the community growth is quite high so that there is a surplus of labor force supplies. The labor oversupply lowers the average wage. On the contrary, in urban areas, the industry sector experiences scarcity of labor force. It attracts many labor force to migrate from the primary sector to the secondary, therefore, there is a migration and urbanization process. Besides, the country's rate of income is increased so that the community tends to consume various products of the industry and services. This is the main mobilizer for the output growth in the non-agriculture sectors. Chenery's theory focuses on the structural transformation in the process of economic transformation in a country which is having a 
transformation from traditional agriculture into industrial sector as a primary enhancement to the economic growth. The factors causing the economic transition: 1 . The initial economic Condition and Structure in a country. A country which initial economic development had already have the relatively strong fundamental industries will have a fast process of industrialization. 2. The size of the national market is one of the intensive factors for the growth of economic practices including the industry, to guarantee the economic and efficiency scale within the production process. 3. The income distribution pattern. It is a supporting factor in the market. The level of income does not matter for the industrial growth if the distribution is hampered. 4. The Industrialization Characteristics, including the implementation procedure or strategy of industrial development, the type of industry prioritized, the pattern of industrial development, and the incentives given. 5 . The existence of natural resources. There is a tendency that a country which is rich with natural resources experience a lower rate of economic growth, late industrialization, failure in implementing economic diversification (structural transformation) compared to countries with scarce natural resources. 6. The foreign trade policy, for countries which implement a closed economic policy (inward looking policy), their result of industrialization pattern will develop inefficiently compared to countries which implement outward-looking policy.

In Indonesia, since 1983 up to the economic crisis, the role of primary sectors tend to decrease while the secondary sectors (such as manufacture industries; electricity, gas, and water; construction) and tertiary sector (trade, hotel, and restaurant, transport \& communication, bank \& finance, and other economic practices) is significantly increasing. In the agriculture sector itself, there has been an economic structural transformation between the unbalanced subsector and the structural transformation of the share of labor force absorption. The labor loads that is currently happening in agriculture sector is not evenly distributed in each subsector, wherein almost all aspect is handled by the food plant subsector so that the condition of food farmer family is becoming more worrying. Generally, there has been an improvement in Indonesia's human resources quality, it is proven that the community has more composition of secondary to upper education, on the contrary, there are fewer compositions with secondary to lower education. However, the improvement in human resources is not followed by the government's ability to provide employment suitable for that qualification (Tambunan, 2001).

The question is on the condition of economic and labor structures after that period of economic crisis. In fact, Indonesia's economic growth is not followed by a proper labor structural transformation. In other words, the economic sectoral transformation is relatively fast compared to the labor transformation so that the turning point of the economic practices is achieved prior to the turning point of the labor force (Gultom, 2011). Therefore, this paper attempts to observe the objective condition of the economic and labor structures in Indonesia from 2007-2017 by referring to the structural transformation pattern as proposed by scholars the likes of Chenery and Syrquin (1974), an ideal pattern is a transformation pattern from "Primary - Secondary - Tertiary Sector", and the transformation of economic and labor structures proposed by Kuznets.

\section{LITERATURE REVIEW}

Theoretical Studies. Many development theories discussing structural approach started from the thought and view of Arthur Lewis, a pioneer in economic development who considers development as a transition which also consisted of a structural transformation. His ideas in Lewis' two-sector model includes traditional and modern sectors. The traditional sector includes mainly the community agricultural practices as well as informal practices in urban areas (self-employment practices). The economic practices in the traditional sector are entrepreneurial to sustain and maintain the level of consumption necessary for its continuity. The modern sector includes manufacture industries, agriculture, trade, plantation and mining in the medium and big scale (Kamaluddin, 1999).

The role of agriculture sector in developing countries is still major, even though there is a symptom of transformation from agriculture to industrial sector, whether in terms of the size 
of GDP share, absorption of the labor force, or even its contribution to the exports (Hakim, 2004). Generally, the transformation happens in developing countries is a transformation from agriculture to the industrial sector, as Chenery (1960) stated. The economic structure or transformation from traditional into modern is commonly defined as a structural transformation, a shift in the growth of the production sector from primary to secondary sector. This shift of production sector growth directly affects the transformation in the composition of labor, which initial primary job was in agriculture, into industrial, trade, and economic services sectors related to the composition of labor force absorption, production, trade, and other factors required to continuously improve the income and social welfare through the increase of income per capita (Sukimo, 2012). Another important aspect of structural change is the employment that the economic growth through two processes of transformation can be achieved by increasing the labor productivity in each sector and transferring labor from the low labor productivity sectors to higher labor productivity (Clark, 1964 in Suryana, 2000).

The economic structure of countries across the globe have experienced transformations in its economic growth and development process. The economic, as well as labor structural changes, are mainly reflected in the role of economic/labor sectors (Kamaludin, 1998). In this situation, broadly it can be concluded that the primary sector's (agriculture and mining) contribution toward GDP will tend to decrease, while the role of secondary sector (manufacturing industry, construction), as well as the tertiary sector (services), will be heightened along with the country's strengthening economy. Additionally, the higher a country's income per capita, the lower the role of agriculture sector in providing employment and absorbing the labor force, while on the contrary, the industrial sector's role will become more important and significant in absorbing the labor force (Kamaluddin, 1999).

Kuznets (1969) collected and analyzed the data from 13 countries which now are developed (such as England, France, Germany, Dutch, etc) to acknowledge the contribution of various economic sectors in the national production while developing the economy. The conclusion from the study include: a) The contribution of the agriculture sector from 12 out of thirteen countries toward the national production decreased. b) The role of the industrial sector in the national production had been increased. During the early years of the observation, the role was around 20-30 percent and during the final years, it was increased into 40-59 percent. c). The contribution of the service sector in constructing national product did not have any significant and consistent transformation.

In relation to the structural transformation of labor in different business under the influence of economic development, Kuznets concluded: a). The role of the agriculture sector in absorbing labor force decreased in all country studied. Generally, this sector could handle 25-50 percent of the labor force. During the end of the observation, most countries had a decline around 20-50 percent. b). The role of the industrial sector in providing job opportunities had become more important, yet the increase was relatively small except for certain countries, for instances, England, Swedia, Japan, and Russia. c). the role of the service sector in providing job opportunities did not have many transformations in countries like England, Belgium, Dutch, etc. Yet, in some other countries, there was major transformation (increase) in the absorption of the labor force, such as in Swiss, Denmark, Italy, and the United States (Sukimo, 2012).

If the transformation of the roles in each sector of national production and the transformation of the role in each economic sector/employment in absorbing labor force are compared: a) Relatively, in the agriculture sector, the transformation in the sector's contribution toward the national production almost aligns with the transformation of its role (decrease) in providing job opportunities. b). In the industrial sector, the transformation (increase) in the contribution toward the national production is higher than the relative transformation on its role in absorbing labor force. c). in the service sector, the transformation of the role in constructing the national production is lower than the transformation of its role in absorbing labor force.

Empirical Studies (Findings of Previous Studies). Jeffri Minton Gultom, in his article entitled the analysis of economic structure using the shift-share in the province of West 
Sumatera of 1980 - 2009, concludes his research: based on the research findings and assessment with the shift-share method on four economic sectors in West Sumatera from 1980 - 2009, a conclusion composed: 1 . Observed from the shift-share analysis toward the labor force absorption in West Sumatera from 1980 until 2009. The first period of analysis is the year $1980-1989$, where the components of shift-share analysis showed that the labor force absorption of $48.10 \%$ followed by the service sector as much as $24.48 \%$ and trade sector of $20.19 \%$, while the industrial sector was the lowest of the three sectors with $7.24 \%$. furthermore, the second period of analysis is the year 1990-1999 which showed a surprising finding on the remarkable intersectoral transformation in all sector analyzed, the most outstanding one is shown on the agriculture and trade sectors, which had a significant decline and increase in the growths. The agriculture sector, which during the first analysis period was on the top position in terms of labor force absorption, now in the second period of analysis had a drastic decline into $18.24 \%$. Therefore, it positioned the agriculture sector on the lowest position among all the sectors analyzed. Meanwhile, the trade sector in this period of analysis had a gradual increase and became the top four in the growth of labor absorption throughout West Sumatera, which was $41.33 \%$. Other sectors following the success of the trade sector were service sector, where it also had a significant increase and was on the second position with $35.22 \%$. The industrial sector, which previously had a slight increase, this year also had a decline yet not as detrimental as the agriculture sector. The rate of transformation or a decrease in the industrial sector was $5.22 \%$. The third period of analysis, which is from the year 2000-2009, showed the last transformation of these sectors. In this period, all sectoral component analyzed had a positive transformation in terms of increase in the labor force absorption in West Sumatera. Now the trade sector still maintaining its top position in the growth of labor force absorption, yet it had a slight decrease into $36.40 \%$. It is then followed by the restoration in the agricultural sector, which previously had a detrimental decline. And now the agriculture sector showed a promising improvement in absorbing the labor force as much as $33.42 \%$. The following sectors are service and industry, where its growths respectively were $24.60 \%$ and $5.58 \%$. The service sector had also been restored from its lowest point in the previous period, even though now it is still in the lowest position among the sectors analyzed. 2. Assessed from the shift-share analysis results for the contribution of PDRB in West Sumatera from 1980 until 2009. The number of shift-share analysis components from the first period of analysis 1980-1989 showed that the agriculture sector was the sector that had the biggest growth in terms of contribution toward PDRB of West Sumatera, which was $51.28 \%$ followed by trade sector of $35.34 \%$ and industrial sector of $16.04 \%$. Meanwhile, the service sector was considered as the lowest with a decrease in the growth of contribution toward PDRB of West Sumatera, which was $2.67 \%$. Furthermore, the second period of analysis, which was from 1990-1999, showed that the growth of sectors analyzed had an increase in its contribution toward PDRB of West Sumatera. The top position during this period was still agriculture sector, even though the percentage had a decline compared to the previous years.

Andi Tri Pambudi (2011), in his article entitled The Shift of Economic Structure based on the Labor Force Absorption in Central Java concludes: Analyzed from the LQ analysis result for labor force absorption in Central Java of 2004-2008. The sectors which had LQ value > 1 form 2004-2008 were industrial, construction, and trade sector. The industrial sector was the sector that had LQ value growing from 2004 as much as 1.328 into 1.429 in 2008. The construction and trade sectors had LQ values which decreased from 2004-2008. 2. The shift-share analysis result in Central Java of 2004-2008 can be concluded into that the overall influence of the biggest shift-share components $(\Delta \mathrm{Er})$ was the industrial sector as much as Rp. 9,163.35 million, it is also the sector with $10.99 \%$ growth on the labor force absorption from 2004-2008. The overall influence of shift-share component $(\Delta \mathrm{Er})$ of trade sector was Rp. 7,283.15 million with the growing labor force absorption from 2004-2008. The sectors with the influence of share-shift component were Electricity, Gas, and Water of Rp. 339,55 million with the decreasing labor force absorption from 2004-2008. 3. The result of Tipologi Klassen analysis in Central Java of 2004-2008 concluded that the agriculture, industrial, and service sectors were considered as developed and fast-growing sectors. 4. 
The economic structure in Central Java had a shift from agriculture sector (traditional) to the industrial sector (modern). This can be seen from the industrial sector that had become the priority sector in absorbing the labor force, one of the sectors which economic performance was relatively growing faster, that made the industrial sector to be a fast-growing and developing sector. This shift was followed by the shift of labor force absorption, contribution, and growth of PDRB in the agriculture and industrial sectors.

\section{METHODS OF RESEARCH}

This research is a descriptive research aimed to describe aspects which are currently applicable. It includes the attempts to describe, record, analyze, and interpret the conditions which are happening or not (Sugiyono, 2010). The data analysis uses the secondary data in a form of Gross Domestic Product Indonesia on the Basic Price Applies and the population data of 15 years old and above in accordance with the main employment/job opportunity within the period of 2007-2017, sourced from the Central Bureau of Statistics, Republic Indonesia (RI).

The data is analyzed using the contribution formula of the main economic sector/business fields/main employment:

- $\mathrm{Ks}=\mathrm{VAs} / \mathrm{PDB} \times 100 \%$, where $\mathrm{Ks}$ is the sectoral contribution, VAs is the sectoral added-value, PDB is Produk Domestik Bruto (Gross Domestic Product);

- $\quad \mathrm{DTk}=\mathrm{LU} / \mathrm{LPU} \times 100 \%$, DTk is the percentage of labor force distribution according to the business fields; LU is the Lapangan Usaha (Business Fields): total Lapangan Usaha Utama (The Main Business Fields).

This research, the economic sector/Business Fields/Main Employment refers to (BPS RI 2014):1. Agriculture; 2. Mining and Extraction; 3. Manufacturing Industry; 4. Electricity, Gas, and Clean Water; 5. Construction; 6. Trade, Hotel, and Restaurant; 7. Shipping and Communication; 8. Finance, Renting, and Company Services; 9. Services. From those nine sectors/Business Fields, for the research purposes, are divided into three main sectors including Primary (sector no. 1-2); Secondary (sector no. 3-5); and Tertiary (sector 6-9) sectors/Business Fields (BPS RI, 2014).

\section{RESULTS AND DISCUSSION}

Economic and Labor Structures. The economic and labor structures can be explained by looking at each sector's contribution toward the Gross Domestic Product and the labor force absorption within the respective business field in relation to the main business fields. In other words, the indicator of the economic and labor force structures is the contribution of each sector/business field toward the overall economic sector/main business fields. The condition of Indonesia's economic structure of 2007-2017 can be seen in Table 1.

Table 1 - The Percentage of Economic Sector's Distribution toward PDB Indonesia upon the Basic Price Applies of 2007-2017

\begin{tabular}{|c|c|c|c|c|}
\hline Year & $\begin{array}{c}\text { (\%) PRIMARY (P) } \\
\text { Sector }\end{array}$ & $\begin{array}{c}\text { (\%) SECONDARY (S) } \\
\text { Sector }\end{array}$ & $\begin{array}{c}\text { (\%) Tertiary (T) } \\
\text { Sector }\end{array}$ & $\begin{array}{c}\text { Pattern of Contribution Order } \\
\text { (high-low) }\end{array}$ \\
\hline 2007 & 21.00 & 45.00 & 35.00 & $\mathrm{~S}-\mathrm{T}-\mathrm{P}$ \\
\hline 2008 & 21.00 & 44.00 & 35.00 & $\mathrm{~S}-\mathrm{T}-\mathrm{P}$ \\
\hline 2009 & 21.00 & 44.00 & 35.00 & $\mathrm{~S}-\mathrm{T}-\mathrm{P}$ \\
\hline 2010 & 22.00 & 44.00 & 34.00 & $\mathrm{~S}-\mathrm{T}-\mathrm{P}$ \\
\hline 2011 & 22.00 & 46.00 & 32.00 & $\mathrm{~S}-\mathrm{T}-\mathrm{P}$ \\
\hline 2012 & 23.00 & 44.00 & 33.00 & $\mathrm{~S}-\mathrm{T}-\mathrm{P}$ \\
\hline 2013 & 23.00 & 43.00 & 34.00 & $\mathrm{~S}-\mathrm{T}-\mathrm{P}$ \\
\hline 2014 & 24.00 & 41.00 & 35.00 & $\mathrm{~S}-\mathrm{T}-\mathrm{P}$ \\
\hline 2015 & 24.00 & 41.00 & 35.00 & $\mathrm{~S}-\mathrm{T}-\mathrm{P}$ \\
\hline 2016 & 23.00 & 41.00 & 36.00 & $\mathrm{~S}-\mathrm{T}-\mathrm{P}$ \\
\hline 2017 & 22.00 & 41.00 & 37.00 & $\mathrm{~S}-\mathrm{T}-\mathrm{P}$ \\
\hline
\end{tabular}

Source: BPS RI, 2017 (processed secondary data). 
The level of uneven economic growth or production without the labor force absorption ability will bring a consequence in a form of structural transformation from both aspects, which will be worse whether among sectors or subsectors in each sector. Referring to the findings stated by Simatupang and Mardianto (1996), in 1960, the pattern of PDB Indonesia's structure was P-T-S, and the findings of Kariyasa (2004) added, with the contribution order of $\mathrm{P}-\mathrm{T}-\mathrm{S}$, it can be assumed that there was a fast structural transformation in the production (PDB) from P-T-S to T-S-P into S-T-P, therefore, the contribution of the agriculture sector was dramatically shifted into the lowest position.

Throughout the period of 2007-2017, the contributions of Primary and Secondary sectors had been having a gradual decline, while the Tertiary sector had been increased since the beginning (2007) until the end of period (2017). Referring to the theories of Chenery and Sirquin and Kuznets, a structural economic transformation happens if the contribution of the primary sector toward the national production decreases, while the contribution of the secondary sector increases with the ideal transformation pattern, like the ones that happened in the now developed countries, which is a transformation pattern from the primary to secondary sectors, and finally the tertiary sector $(\mathrm{P}-\mathrm{S}-\mathrm{T})$. The data analysis result of Indonesia in 2007-2017 show an ideal transformation pattern, which indicates Indonesia's economic structure in the period was industrial (secondary) due to the fact that it was the dominant sector in contributing to the national production.

The economic structural transformation with that pattern is caused by many factors, such as the human consumptive behavior, which is if their incomes are increased, their demand sensitivity becomes low specifically for food materials, yet, the demand toward nonfood materials becomes high. This aligns with Engel law (Kamaluddin, 1999) that states the higher the community's income is, the fewer the income proportion used to purchase agricultural/food materials (primary) and, on the contrary, the income proportion used to purchase industrial goods (secondary) increases. The economic structural transformation is also caused by the technological advancement along the development process that will enhance the transformation of production structure, whether it is compulsory (not or not yet needed by the traditional community) or inductive (new manufacturing of goods to diversify the consumptive choices).

Table 2 - The Percentage of Labor Force Distribution based on the Main Business Field in Indonesia 2007-2017

\begin{tabular}{|c|c|c|c|c|}
\hline Year & $\begin{array}{c}\text { (\%)PRIMARY } \\
(\mathrm{P}) \text { Sector }\end{array}$ & $\begin{array}{c}\text { (\%) SECONDARY } \\
(\mathrm{S}) \text { Sector }\end{array}$ & $\begin{array}{c}\text { (\%) TERTIARY } \\
(\mathrm{T}) \text { Sector }\end{array}$ & Pattern of Contribution Order (high-low) \\
\hline 2007 & 46.00 & 16.00 & 38.00 & $\mathrm{P}-\mathrm{T}-\mathrm{S}$ \\
\hline 2008 & 46.00 & 18.00 & 36.00 & $\mathrm{P}-\mathrm{T}-\mathrm{S}$ \\
\hline 2009 & 44.00 & 16.00 & 40.00 & $\mathrm{P}-\mathrm{T}-\mathrm{S}$ \\
\hline 2010 & 43.00 & 17.00 & 40.00 & $\mathrm{P}-\mathrm{T}-\mathrm{S}$ \\
\hline 2011 & 42.00 & 18.00 & 40.00 & $\mathrm{P}-\mathrm{T}-\mathrm{S}$ \\
\hline 2012 & 42.00 & 18.00 & 40.00 & $\mathrm{P}-\mathrm{T}-\mathrm{S}$ \\
\hline 2013 & 41.00 & 18.00 & 41.00 & $\mathrm{P}-\mathrm{T}-\mathrm{S}$ \\
\hline 2014 & 38.00 & 20.00 & 42.00 & $\mathrm{~T}-\mathrm{P}-\mathrm{S}$ \\
\hline 2015 & 37.00 & 21.00 & 42.00 & $\mathrm{~T}-\mathrm{P}-\mathrm{S}$ \\
\hline 2016 & 36.00 & 20.00 & 44.00 & $\mathrm{~T}-\mathrm{P}-\mathrm{S}$ \\
\hline 2017 & 35.00 & 20.00 & 45.00 & $\mathrm{~T}-\mathrm{P}-\mathrm{S}$ \\
\hline
\end{tabular}

Source: BPS RI , Survei Angkatan Kerja Nasional 2007-2017 (processed).

The result of data analysis on the labor structure is shown in Table 2, which depicts the fact that from 2007 until 2013, the primary sector was still dominant as the sector that absorbed the labor force, yet, from year to year throughout the period of this research there was a decrease in its contribution to the total main business field. It indicates that there was a labor structural transformation even though the pattern was from primary to tertiary sector, and then to the secondary sector (not ideally from primary to secondary and then to tertiary as proposed by Kuznets or Chenery and Sirquin, 1960). This is caused by the number of 
labor forces absorbed by the traditional tertiary sector (Lewis' two-sector model), just like the informal sector that became a safety valve for unemployment.

Referring to Lewis' two-sector model, the productivity in a traditional sector is far lower compared to in the modern sector. The marginal product of labor force in the traditional sector tends to move toward a level below the average product, or even close to zero. In this case, the phenomenon of unemployment would not be noticeable. The urban modern sector fulfills the demand of labor forces by drawing it from the traditional sector in the rural areas. With the increase in population, the supply of labor forces would seem to be unlimited.

In Table 2, it can be seen that the contribution of the primary sector in the labor force absorption is decreased, while the secondary sector had a constant increase from the beginning of the observation until the end. The tertiary sector also had an improvement in the labor force absorption throughout 2007-2017. Such condition indicates that there was a structural labor transformation with a pattern of primary - tertiary - secondary (Pattern P - T $-\mathrm{S}$ ) instead of primary - secondary - tertiary.

\section{CONCLUSION}

1. There had been an economic structural transformation (the contribution of economic sectors toward PDB) in Indonesia from 2007-2017 with the pattern of Primary - Secondary Tertiary.

a. The contribution of the primary sector in the national production of 2007-2017 had been improved from 20 percent to 22 percent at the end of the observation period.

b. The secondary sector's role in constructing the national production had been lowered from 45 percent into 41 percent.

c. The contribution of the tertiary sector in creating the national production had been improved from 35 percent into 37 percent throughout the period of observation.

2. There had been a labor structural transformation in various sectors/business fields due to the economic development process with the transformation pattern of Primary Tertiary - Secondary sectors.

a. The primary sector's role in the labor force absorption had been lowered from 46 percent at the beginning of the observation (2007) into 35 percent at the end of the observation period (2017).

b. The secondary sector's role in providing job opportunity becomes more important. There had been an improvement from 1 percent into 20 percent by the end of the period (2017).

c. The tertiary sector's role in the labor force absorption also had been improved from 38 percent (2007) into 45 percent (2017).

3. The comparison between the role transformations in each economic sector in creating the national production and the role transformations of economic sector/main business fields in the labor force absorption concludes that:

a. In the primary sector, the relative transformation in its sectoral contribution toward the national production is lower than the relative transformation of its labor force absorption role.

b. In the secondary sector, the relative transformation in creating the national production is higher than its relative transformation of its labor force absorption role.

c. In the tertiary sector, the relative transformation in creating the national production is lower than the relative transformation in the labor force absorption.

\section{RECOMMENDATIONS}

As an anticipation to the buildup of labor forces in the primary sector, which commonly happens in the rural areas, the rural-based industrial development is necessary, with a hope that, on one hand, it can absorb the surplus of labor forces and, on another hand, add values for the agricultural products (primary). Therefore, it eventually can slow down the process of impoverishment in the agriculture sector. 
The agricultural technological development in areas with the oversupply of the labor force is better to be channeled into the labor-intensive technological innovations so that the problems of labor force oversupply could be properly handled.

\section{REFERENCES}

1. Badan Pusat Statistik RI. (2014). Produk Domestik Bruto Atas Dasar Harga Berlaku Indonesia 2004-2014. Jakarta: BPS.

2. (2014). Penduduk Berumur 15 Tahun Ke Atas Menurut Lapangan Pekerjaan Utama 2004-2014. Jakata: BPS.

3. Chenery, H. B. (1960). Pattern of Industrial Growth. Oxford: Oxford University Press.

4. Gultom, J. M. (2011). Analisa Struktur Perekonomian Berdasarkan Pendekatan Shit Share Di Provinsi.

5. Sumatra Barat 1980-2009 (Unpublished Thesis). Universitas Andalas, Padang.

6. Hakim, A. (2004). Ekonomi Pembangunan. Yogyakarta: Ekonisa Kampus FE-UII.

7. Kamaluddin, R. (1999). Pengantar Ekonomi Pembangunan. Jakarta: Lembaga Penerbit FEUI.

8. Mubyarto. (2001). Prospek Otonomi Daerah dan Perekonomian Indonesia Pasca Krisis Ekonomi. Yogyakarta: BPFE-UGM.

9. Pambudi, A. T. (2011). Pergeseran Struktur Perekonomian Atas Dasar Penyerapan Tenaga

10. Kerja Di Provinsi Jawa Tengah (Unpublished Thesis). Fakultas Ekonomi Universitas Diponegoro, Semarang.

11. Simatupang, P., \& Sudi, M. (1997). Pengaruh Kebijaksanaan Moneter dan Kurs Valuta Asing terhadap Transformasi Struktur Perekonomian Indonesia. Prosiding Seminar Nasional PERHEPI "Pertanian dan Pedesaan Indonesia dalamTransisi: Refleksi dan Perspektif".

12. Sugiyono. (2010). Statistika Untuk Penelitian. Alfabeta: Bandung.

13. Sukirno,S. (2000). Ekonomi Pembangunan. Jakarta: Lembaga Penerbit FE-UI.

14. Suryana. (2000). Ekonomi Pembangunan Problematika Dan Pendekatan. Jakarta: Salemba. Empat.

15. Tambunan, T. T. H. (2001). Perekonomian Indonesia.Teori Dan Temuan Empiris. Jakarta: Ghalia. Indonesia.

16. Todaro, P. M. (1983). Economic Development in the Thirt World. USA: Longmen Inc.

17. Widodo, T. S. (1990). Indikator Ekonomi Dasar Perhitungan Perekonomian. Indonesia. Jakarta: Kanisius. 